\title{
液体麴による合成清酒香味液 醸造の機械化に関する研究
}

第 15 報 高濃度の培養基に扣ける液体麴液中の罡元糖, 水淮性 蛋白質並にアミラーゼの現象について

沢崎輝藏, 饭田茂次

(昭和 34 年 2 月 11 日受理)

緒

言

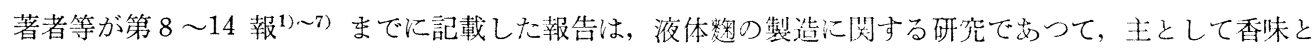
酵素力価の上界に主眼を置いて研究し, 一応の合成清酒用香味液酸慥の成韻を得る机が出来た。本研究て

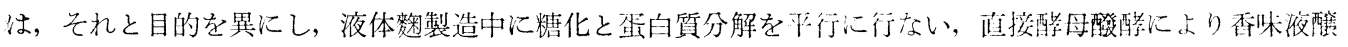

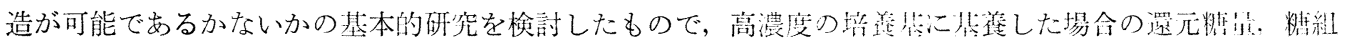
織及び蛋白質分解濃度，アミラーゼの消長就て簡単汇報告する。

\section{1. 可溶性澱粉の高濃度と培養中に生産される還元性糖の現象に就て}

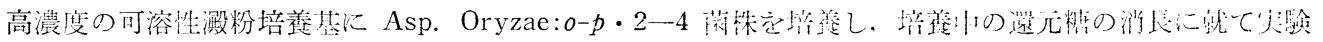

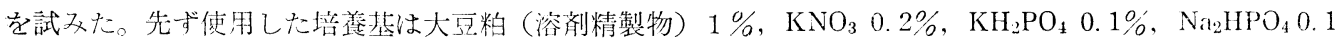

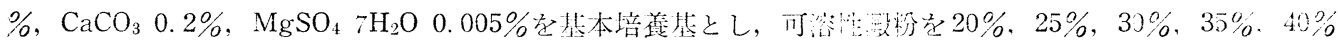

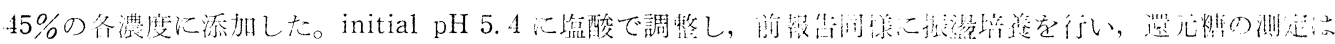

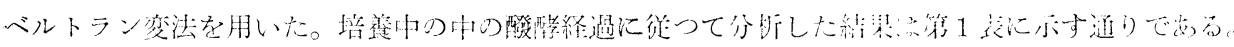

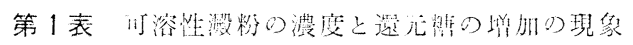

\begin{tabular}{|c|c|c|c|c|c|c|c|}
\hline \multirow{2}{*}{ 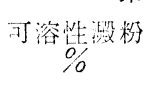 } & \multicolumn{2}{|c|}{ 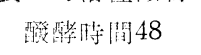 } & \multicolumn{2}{|c|}{ 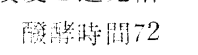 } & \multicolumn{2}{|c|}{ 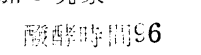 } & \multirow{2}{*}{ 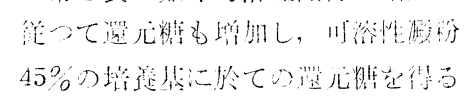 } \\
\hline & $\overline{\mathrm{pH}}$ & 䢱元湆; $\%$ & $\mathrm{pH}$ & 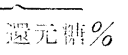 & $\overline{\mathrm{pH}}$ & 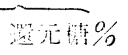 & \\
\hline 45 & 5.8 & 7.07 & 5.5 & 15.9 & 5.1 & 15.5 & 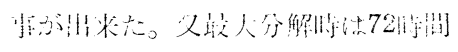 \\
\hline 40 & 5.8 & 6.1 & 5.5 & 14.94 & 5.1 & 13.0 & 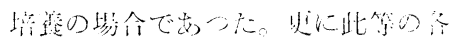 \\
\hline 35 & 5.9 & 5.7 & 5.5 & 11.38 & 5.1 & 11.0 & 液の㴧液を paper-chlomat@- \\
\hline 30 & 6.1 & 4.9 & 5.5 & 9.4 & 5.0 & 10.4 & 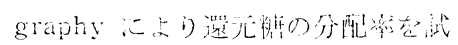 \\
\hline 25 & 6.2 & 3.9 & 5.2 & 7.14 & 5.0 & 6.24 & 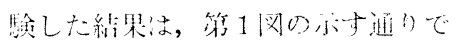 \\
\hline 20 & 6.1 & 3.0 & 5.1 & 5.2 & 4.8 & 4.3 & \\
\hline
\end{tabular}

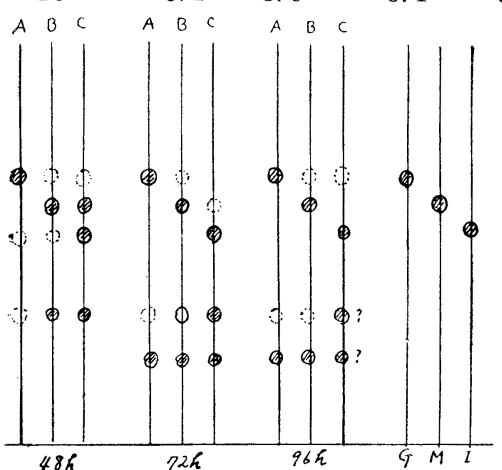

第 1 図 培養液のPaper chlomatography

可僢性筫粉

$\mathrm{A}=20 \% \mathrm{G}=$ - lucose 溶剂Pyridine 2 :

$\mathrm{B}=35 \% \quad \mathrm{M}=$ maltose $\mathrm{BuOH} 3: \mathrm{H}_{2} 0.15$

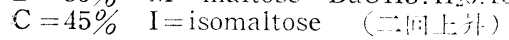

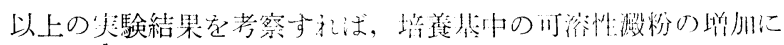

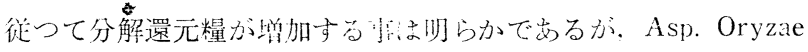
菌株に於てはTrans-o-glucosidase の性:听をも有し，义アミラー

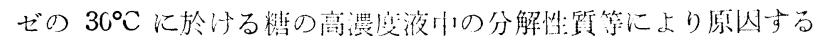

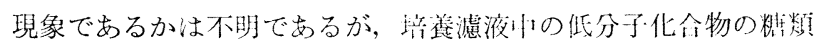
の検討にpaper-chlomatography 法を朋いた結果汇㸝ては，可控 性澱粉20\%の場合は glucose の処汇莀厚な Spot が垷九，35\%

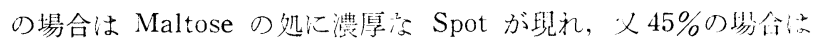

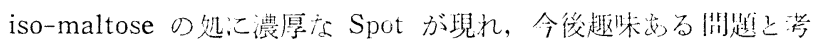
觉られる。

\section{II. 窒素化合物を增斺した場合の還元糖の現象に就て}

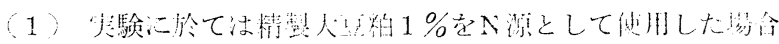

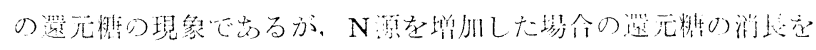
梌湖した。

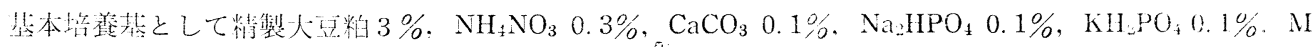

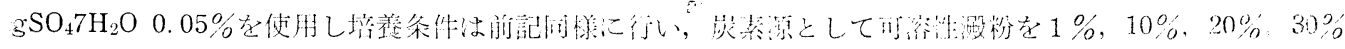

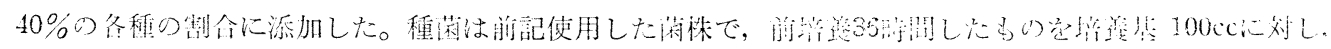

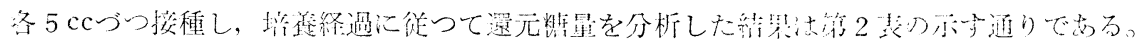


第 2 表 窒素源と墇養中の精元還の消長

\begin{tabular}{|c|c|c|c|}
\hline 可溶狌 & 酸醥時阔 48 & 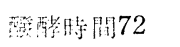 & 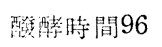 \\
\hline & $\mathrm{pH}$ 還元精 & $\mathrm{pH}$ 還元精 $\%$ & $\mathrm{pH}$ 還 \\
\hline
\end{tabular}

第 3 表 空素源と培養中心還元糖及び水溶 性窒素の消長

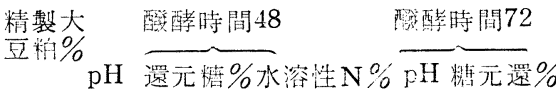

$\begin{array}{llllll}1 & 5.9 & 12.6 & 0.14 & 5.6 & 13.4\end{array}$

$\begin{array}{llllll}2 & 5.8 & 13.4 & 0.22 & 5.5 & 13.4\end{array}$

$\begin{array}{llllll}3 & 5.8 & 13.2 & 0.25 & 5.7 & 13.4\end{array}$

20

$5.5 \quad 0.99$

$5.5 \quad 1.53$

5. $4 \quad 0.94$

6. 0

4. 6

$6.0 \quad 6.3$

6. $0 \quad 7.9$

6. $0 \quad 8.7$

$4 \quad 5.8 \quad 13.2$

0.28

5.313 .6

5. $8 \quad 10.2$

$5 \quad 5.8$

13. 4

0.28

6. $0 \quad 13.5$

又基本培養基中の $\mathrm{NH}_{4} \mathrm{NO}_{3}$ を除き， $\mathrm{CaCO}_{3}$ を $0.2 \%$ に增加した培地に精製大豆粕 $1 \% ％ ２ \% ， 3 \% ， 4$ \%，5\%を备種混合した場合の培養基に就て検討した結果は第 3 表の示す通りである。

水溶性窒素の分析法はヶルダル法に従い水溶液中のNを測定した。

以上の結果は第 2 表, 3 表の如く可溶性澱粉の増加に従つて, 培養基中の窒素源に関係なく澴元糖の增加 が見られた。然し第 2 表に比較して硝酸アンモニウムの有無によつて，培㡺液中にての還元糖の菌体による 消費現象が認められた。即ち硝酸アンモニウムの含有の場合，一般的に培養48時間に比較して96時間では還 元燃の消費が多いことを示している。然るに加里塩に於ては消費は認められなかつた。又潞素源の分解度は 多少の差が有るが，還元糖の現象の㥞ではなかつた。

\section{III. 高濃度の可溶性澱粉培養基とアミラーゼの生産量との関係に就て}

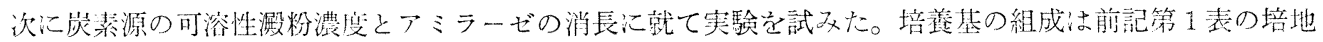

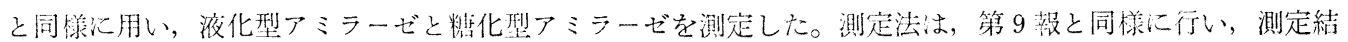
果:は籍4表の示与通りである。

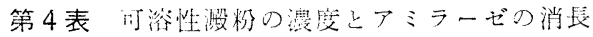

\begin{tabular}{|c|c|c|c|c|c|c|c|c|c|}
\hline \multirow{2}{*}{$\begin{array}{c}\text { 可溶性清粉 } \\
\%\end{array}$} & \multicolumn{3}{|c|}{ 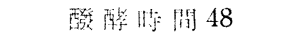 } & \multicolumn{3}{|c|}{ 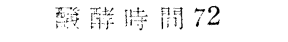 } & \multicolumn{3}{|c|}{ 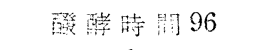 } \\
\hline & $\mathrm{pH}$ & W. V & R. D. V & $\mathrm{kH}$ & W. V & R. D. V & $\mathrm{pH}$ & W. V & R. D. V \\
\hline 45 & 5.8 & 5.0 & 19.6 & 5.5 & 50 & 12.0 & 5.1 & 50 & - \\
\hline 40 & 5.8 & 75 & 18.3 & 5.5 & 50 & 16.0 & 5.1 & 50 & 15 \\
\hline 35 & 5.9 & 75 & 19.5 & 5.5 & $40 \sim 75$ & 18. 0 & 5.1 & 62 & 6 \\
\hline 30 & 6.1 & 100 & 18.3 & 5.5 & 75 & 15.0 & 5.0 & 75 & 15 \\
\hline 25 & 6.2 & 100 & 10.0 & 5.2 & 75 & 15.0 & 5. 0 & 75 & 16 \\
\hline 20 & 6.1 & 100 & 17.0 & 5.1 & 100 & 3. 0 & 4. 8 & 75 & 0 \\
\hline
\end{tabular}

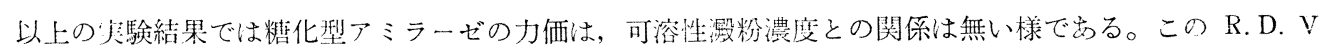

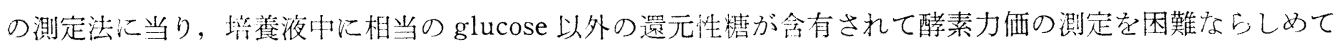
いるにしても，一様の現象として認められると思５。双液化型アミラーゼは濃度が増加するに従つて醉素力 価が減少する傾向を示している。

\section{考 察}

以上の実験結果を考察与れば，可溶性澱粉培養基に於て，炭素源の増加に従つて培養液中の含有還元糖も 大となつた。又培養液中の還元糖を paper-chlomatography 法により検討した処, maltose, iso-maltose, glucose の出現が可溶性澱粉の濃度により異なる事を知つた。又培荃基中の窒素源の增加は, 培養液中の含 有㵋元糖量の增加と無関係であり，更に又水溶性窒素含有量の增加の現象はあまり認められなかつた。

此等の現象は，使用菌の培埕基に対する特異性によつて多少の差があると考えられるが，ここに使用した 菌株は糖化を主とした物でかる。

終りに臨み終始御懇切な御指浆を賜つた坆口諤一郎博上に心から感謝の意を表すると共に，本研它は合成 清酒酒造組命及び国税庁の砸究補助金により行つたもので，僧せて感謝の意を表する次第であります。

\begin{tabular}{|c|c|c|c|c|}
\hline 1) & 钢田, & 本溍 & Vol. 52 & 119 \\
\hline 2) & " & " & Vol. 52 & 217 \\
\hline 3) & "1 & " & Vol. 52 & 467 \\
\hline 4) & " & " & Vol. 52 & 720 \\
\hline 5) & "1 & "I & Vol. 52 & 801 \\
\hline
\end{tabular}

$$
\begin{aligned}
& \text { 参考文 献 }
\end{aligned}
$$

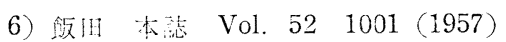

$$
\begin{aligned}
& \text { 7) " " Vol. } 53 \quad 80 \text { (1958) }
\end{aligned}
$$

